\title{
Production and characterization of monoclonal antibodies to four Egtved virus structural proteins
}

\author{
N. Lorenzen, N. J. Olesen, P. E. Vestergård Jørgensen \\ National Veterinary Laboratory, Hangøvej 2, DK-8200 Århus N, Denmark
}

\begin{abstract}
With the aim of studying molecular mechanisms of virulence and immunogenesis of Egtved virus, monoclonal antibodies (MAbs) were produced against 4 dominant virus proteins (G, N, $M_{1}$ and $\mathrm{M}_{2}$ ). The reactivity of each MAb was determined by ELISA, immunoblotting, immunofluorescence and plaque neutralization. Antibodies specific for each of the 4 proteins, as demonstrated by immunoblotting, gave characteristic reactions in ELISA as well as immunofluorescence. None of the MAbs were able to neutralize virus in vitro. When analysed in immunofluorescence using cell cultures fixed at different times after inoculation with live virus, the $\mathrm{N}$-protein was first to be detected followed by $\mathrm{M}_{1}, \mathrm{G}$ and $M_{2}$. G-specific MAbs reacted with either a 'reticular', or a 'Golgi'-form of the G-protein. Results are consistent with published information on the protein compositon and cellular appearance pattern of other rhabdoviruses studied in vitro.
\end{abstract}

\section{INTRODUCTION}

Egtved virus, the causative agent of viral haemorrhagic septicaemia (VHS) of rainbow trout Salmo gairdneri, is one of the most severe pathogens encountered in European trout farms. The virus apparently belongs to the lyssa virus group in the rhabdovirus family (Lenoir \& de Kinkelin 1975, McAllister \& Wagner 1975). Attempts to develop vaccines on the basis of inactivated or attenuated virus have not so far led to products inducing sufficient protection against VHS (de Kinkelin et al. 1984).

It remains to be seen, however, whether improved VHS-vaccine potency might be obtained in artificial vaccines containing primarily or exclusively the virus antigens which induce protective immunity in fish. Such vaccines would have to be based on a detailed study of the molecular mechanisms of virulence and immunogenesis. Such a study requires separation and purification of the 5 polypeptides of Egtved virus which have been designated L (RNA-dependent RNA polymerase), G (envelope glycoprotein), N (nucleocapsid related protein), and $M_{1}$ and $M_{2}$ (matrix proteins 1 and 2) according to the accepted nomenclature of Rabies virus proposed by Wagner et al. (1972). A possible means of obtaining the virus polypeptides in pure form is affinity chromatography based on specific monoclonal antibodies (MAbs).
The present work deals with the production and preliminary characterization of monoclonal antibodies against 4 different polypeptides of Egtved virus strain F1 (Jensen 1965). The methods applied in the characterization of the antibodies were: enzyme-linked immunosorbent assay (ELISA), immunoblotting, immunofluorescence (IFAT), double-diffusion and plaque neutralization ( $50 \%$ PNT).

\section{MATERIALS AND METHODS}

Fish cell lines. For production of virus Bluegill fry (BF-2) cells (Wolf \& Quimby 1962) were used. Epithelioma papulosum cyprini (EPC) cells (Fijan et al. 1983) were utilized for preparation of virus-infected cell cultures for IFAT and $50 \%$ PNT. Both cell lines were cultivated in stationary bottles and trays in Eagle's MEM supplemented with $2 \%$ or $10 \%$ foetal bovine serum and antibiotics in standard concentrations. Buffers used were bicarbonate when cultivation was in bottles, and Tris when cultivation was in open vessels. Cultivation temperature was 20 and $25^{\circ} \mathrm{C}$ for $\mathrm{BF}-2$ and EPC cells, respectively. After inoculation of cell cultures with virus, incubation was performed at $15^{\circ} \mathrm{C}$.

Viruses. Egtved virus, reference strain F1 (Jensen 1965) at passage level 254 , was concentrated and gradient-purified as described by de Kinkelin (1972) for 
immunization of mice as well as for use in ELISA and SDS-PAGE (sodium dodecyl sulphate polyacrylamide gel electrophoresis). Rhabdovirus anguilla (EVX) (Hill et al. 1980), purified following the same procedure, was used as control antigen when the specificity of antibodies was tested in ELISA and by immunoblotting. For preparation of virus-infected cultures for immunofluorescence the following virus strains were used: Egtved virus field strains Gelsbro (serologically related to reference strain F1), EVX and spring viraemia of carp (SVC) virus (Fijan et al. 1971).

Immunization of mice. Six-wk-old female mice $(\mathrm{BALB} / \mathrm{c})$ were given 5 intraperitoneal injections of $10^{8}$ to $10^{9} 50 \%$ tissue culture infective doses (TCID 50 ) over a period of $2 \mathrm{mo}$. For the first 3 injections virus was mixed with equal parts of Freund's incomplete adjuvant. Two mice were given an intravenous booster injection of $10^{9}$ TCID $_{50}$ in Week 9 when ELISA and IFAT had documented the presence in the mice of Egtved-virus-specific antibodies. Three d after the booster the mice were killed and the spleens removed for fusion.

Cell fusion. Spleen cells from the immunized mice were fused with cells of the non-immunoglobulinsecreting myeloma cell line P3-X63-Ag8.653 (Kearney et al. 1979) according to the procedure described by Astaldi et al. (1980). About $2 \times 10^{7}$ myeloma cells and $10^{8}$ mouse spleen cells were mixed in cell culture medium RPMI 1640 (Gibco). The cells were spun down at $400 \times g$ for $10 \mathrm{~min}$ at $6^{\circ} \mathrm{C}$ and subsequently resuspended in $0.5 \mathrm{ml}$ RPMI 1640 medium with $50 \%$ polyethylene glycol (PEG) 4000 (Merck). After resuspension the cells were diluted over 5 min with $10 \mathrm{ml}$ RPMI 1640, pelleted and washed once in medium supplemented with $15 \%$ bovine serum, $10^{-4} M$ hypoxantine, $4 \times 10^{-7} \mathrm{M}$ aminopterine and $1.6 \times 10^{-5} \mathrm{M}$ thymidine (HAT-medium). The cells were then plated on five 96-well tissue culture trays (Costar) in the above HAT medium supplemented with $4 \%$ human endothelian cell supernatant (HECS) from Costar

Cultivation of hybridoma cells. The hybridoma cells were grown at $37^{\circ} \mathrm{C}$ in an atmosphere containing $6 \%$ $\mathrm{CO}_{2}$ and $80 \%$ humidity. Ten d after fusion the HAT medium was replaced by HI medium without HECS From this point on it was attempted to maintain a 50 to $90 \%$ cell confluency by changing the medium at 2 to $4 \mathrm{~d}$ intervals and by varying the serum concentration in the medium between 5 and $15 \%$.

Cloning. Hybridoma cell lines were cloned at least twice by limiting dilution, in order to obtain stable clones of immunoglobulin(Ig)-secreting cell populations.

ELISA. The assay used for screening of hybridoma supernatants (HSNs) was designed according to the principles of indirect ELISA described by Voller et al.
(1979). Microtiter plates were coated overnight at $4{ }^{\circ} \mathrm{C}$ with $50 \mu \mathrm{l}$ per well of either purified Egtved virus diluted 11000 in phosphate-buffered saline (PBS), pH 7.2 , or of PBS alone. After temperature alignment for $1 \mathrm{~h}$ at room temperature (the following steps were all performed at room temperature) the plates were washed once in PBS with $0.05 \%$ Tween 20 (PBS-T) followed by blocking with PBS-T with $1 \%$ bovine serum albumin (BSA) (PBS-T-BSA), $200 \mu$ per well, for $1 \mathrm{~h}$. After 3 additional washings the microtitre plates were incubated for $1 \mathrm{~h}$ with $50 \mu \mathrm{l}$ per well of the HSNs to be examined. A serum pool from mice immunized with Egtved virus strain F1 was used in dilution 1:1000 (later bleedings $1: 10000$ ) as a positive standard. The washing procedure was repeated and followed by a $1 \mathrm{~h}$ incubation with horse radish peroxydase (HRP)-conjugated rabbit Ig to mouse Ig (Dakopatts, Copenhagen) diluted 1:1000 in PBS-T-BSA, $50 \mu \mathrm{l}$ per well.

Finally, after renewed washing, the bound enzyme was visualized using $\mathrm{H}_{2} \mathrm{O}_{2}$-OPD substrate $\left(50 \mathrm{ul} \mathrm{well}^{-1}\right)$. The colour reaction was stopped with $2 \mathrm{MH}_{2} \mathrm{SO}_{4}(100 \mu \mathrm{l}$ well ${ }^{-1}$ ) when the standard test serum reached maximum absorbance (about $\mathrm{A}_{486}=3$ ) in wells coated with virus (usually after 10 to $20 \mathrm{~min}$ ). Spectrophotometric measurements were done in an automatic spectrophotometer (Kontron SLT 210). In the initial screening a HSN was regarded as ELISA-positive when its $\mathrm{A}_{486}$ was above 0.3 in the virus-coated well, provided that the $\mathrm{A}_{486}$ of the corresponding well coated with PBS did not exeed $50 \%$ of the value with virus antigen.

Sodium dodecyl sulphate polyacrylamide gel electrophoresis (SDS-PAGE). SDS-PAGE was performed according to the method of Laemmli (1970) in 0.7 or $1.5 \mathrm{~mm}$ thick slab gels, using a vertical slab gel system from Pharmacia. The stacking gel contained $3.5 \%$ acrylamide $10.11 \%$ bisacrylamide, and the separating gel $10 \% / 0.31 \%$. Wells in the gels were loaded with about $8 \mu \mathrm{g}$ virus protein per $\mathrm{cm}^{2}$ cross-section area. Molecular weight standards from Kem-En Tec (Hellerup, Denmark) were included in each run. After electrophoresis the gels were either used for immunoblotting or stained by the silver staining method described by Morrissey (1981)

Immunoblotting. The protein bands were transferred from polyacrylamide gels to nitrocellulose membranes (Whatman) in a semi-dry electroblotter (Ancos, Olstykke, Denmark) according to the principles described by Kyhse-Andersen (1984). Free binding sites were blocked by incubation in PBS with $2 \%$ Tween 20 for $3 \mathrm{~min}$. After washing in PBS-T the membranes were cut into 2 to $4 \mathrm{~mm}$ wide strips and incubated overnight at $4{ }^{\circ} \mathrm{C}$ (or occasionally 2 h at room temperature) with the individual HSNs diluted in PBST-BSA. As a positive control reagent, diluted mouse antiserum to strain F1 of Egtved virus was used. HRP- 
conjugated antiserum was the same as in ELISA. Visualization of bound conjugate was performed using 3-amino-9-ethyl carbazole (Sigma) (1 $\mathrm{mg}$ in $100 \mathrm{ml}$ acetone) of which solution $2 \mathrm{ml}$ were added to $50 \mathrm{ml}$ $50 \mathrm{mM}$ sodium acetate buffer $\mathrm{pH}$ 5.5, containing $0.015 \% \mathrm{H}_{2} \mathrm{O}_{2}$. The reaction was stopped after 10 to 30 min by removal of substrate. As a positive control reagent, diluted mouse antiserum to strain F1 of Egtved virus was used. The reaction was stopped when the 4 dominating virus protein bands were clearly stained by the control serum (usually 10 to $30 \mathrm{~min}$ ).

To check the efficiency of the blotting procedure a few strips of the nitrocellulose membranes were routinely stained for total protein with colloidal gold (Moremans et al. 1985).

Plaque neutralization test (PNT). $50 \%$ Plaque neutralization tests were used for screening of HSNs for neutralizing activity. The technique used was basically as the micro-method previously described (Olesen \& Jørgensen 1986) except that complement was omitted.

Indirect fluorescent antibody technique (IFAT). Coverglass cultures, $9 \times 22 \mathrm{~mm}$, of EPC cells were infected with $2 \times 10^{8}$ TCID $_{50}$ per $\mathrm{ml}$ of Egtved virus strain F1 or with $1 \times 10^{7} \mathrm{TCID}_{50}$ per $\mathrm{ml}$ of strain Gelsbro. Control coverglass cultures were infected with EVX or SVC virus. Following 1 rinse in medium without serum the cultures were fixed for $10 \mathrm{~min}$ in acetone, either at $1 \mathrm{~h}$ intervals between 1 and $12 \mathrm{~h}$ post-infection (p. i.) (F1) or at $24 \mathrm{~h} \mathrm{p.} \mathrm{i.} \mathrm{(Gelsbro,} \mathrm{EVX} \mathrm{and} \mathrm{SVC).} \mathrm{The}$ fixed cell cultures were stored at $-20^{\circ} \mathrm{C}$ until used. In IFAT, hybridoma supernatants, undiluted or diluted in PBS, or mouse antiserum to Egtved virus strain F1 diluted 1:100 in PBS, were applied as the first antibody layer and fluorescein isothiocyanate (FITC)-conjugated rabbit antiserum to mouse Ig (Dakopatts, Copenhagen), $1: 40$, as the second antibody layer. Incubation times and temperatures as well as rinsing and mounting procedures were essentially as already described (Jørgensen 1974). Examination was carried out in an Olympus Vanox epifluorescence microscope supplied with a $200 \mathrm{~W}$ mercury lamp, interference filters (Rygaard \& Olsen 1969) and fluorescence oil-objectives $\times 40$ and $\times 100$.

Protein determination. The protein content in suspensions of purified virus was estimated by the dye (Coomassie blue G250, Merck) binding microassay described by Rylatt \& Parish (1982), slightly modified as proposed by Macart \& Gerbaut (1982), by adding $30 \mathrm{mg}$ SDS per l colour reagent. BSA (Sigma) was used as standard protein.

Ig class determination. The Ig class and subclass of the MAbs was determined by means of the Ouchterlony double-diffusion technique applying reagents from Serotec (UK).

Ig quantification in hybridoma supernatants. The concentration of murine antibody in HSNs was estimated by ELISA. Instructions about the procedure as well as a standard reagent (an HSN containing $20 \mu \mathrm{g}$ of mouse Ig per ml) were kindly provided by Dr Claus Koch, the State Serum Institute, Copenhagen. In brief, rabbit Ig against mouse Ig (Dako, Denmark) was applied to the wells of microtitre plates as a catching antibody layer. Second layer was 2-fold dilutions of unknown or standard HSN, third layer was HRP-conjugated rabbit antiserum to mouse Ig. The Ig concentration of unknown HSNs were estimated from the correlation between $\mathrm{A}_{486}$ and dilution factor for the $20 \mu \mathrm{g} \mathrm{ml}^{-1}$ standard HSN.

\section{RESULTS}

\section{SDS-PAGE of purified viruses}

Purified Egtved virus, used for immunization, immunoblotting and ELISA, contained $3 \times 10^{10} \mathrm{TCID}_{50}$ $\mathrm{ml}^{-1}$. The protein content was approximately 50 to $60 \mu \mathrm{g} \mathrm{ml} \mathrm{m}^{-1}$. Examination in SDS-PAGE revealed 5 major bands in silver-stained gels as well as in goldstained blotting strips (Fig. 1, Strip 15). According to the molecular weight standards used the molecular weight of the respective 5 polypeptides were about $190,70,41,28$ and $24 \mathrm{kd}$. Based on the nomenclature of rhabdovirus proteins proposed by Wagner et al. (1972) the major protein bands are called $\mathrm{L}, \mathrm{G}, \mathrm{N}, \mathrm{M}_{1}$ and $\mathrm{M}_{2}$.

Purified EVX contained $2 \times 10^{9} \mathrm{TCID}_{50}$ and the protein concentration was estimated to 15 to $20 \mu \mathrm{g}$ $\mathrm{ml}^{-1}$ Four bands were visible on the gold-stained blotting strips ( 3 major and 1 minor one). The expected high molecular weight L-band was not visible, probably due to low concentration and/or slow migration out of the gel during blotting (Fig. 1, Strip 1).

\section{Hybridoma cell line generation and initial screening}

Ten d after fusion, cell growth was observed in about $95 \%$ of the inoculated 960 wells in the fusion trays. Each well contained 1 to 5 cell clones. About $25 \%$ of the cell cultures produced antibodies which were detectable during the initial ELISA screening $13 \mathrm{~d}$ after the fusion. Subcultivation followed by repeated testing reduced this to about $10 \%$ (92 cell cultures). None of the supernatants from these cultures appeared positive when examined in plaque neutralization test.

In immunoblotting 53 of the 92 tested HSNs gave a detectable reaction with 1 or more of the 4 protein bands $G, N, M_{1}$ and $M_{2}$, the remaining 39 being negative. The 29 cell cultures producing the most strongly 


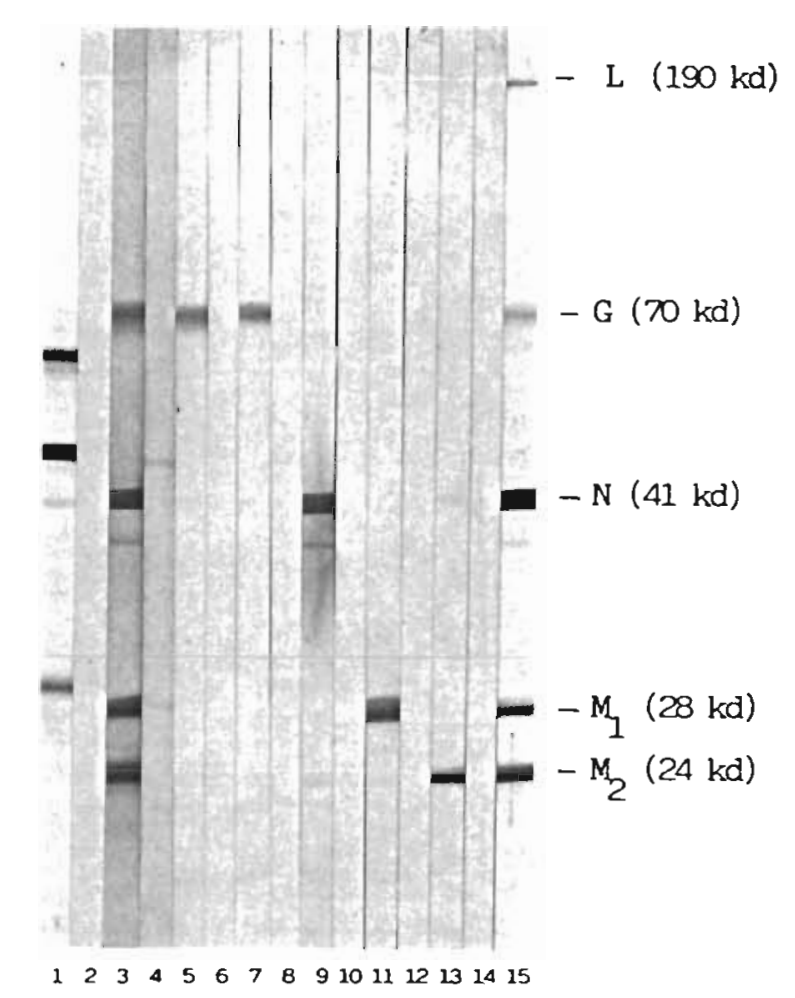

Fig. 1. Immunoblotting with MAbs and mouse serum. After transfer the nitrocellulose membrane was cut into strips which were either stained with colloidal gold or immunostained. Antigens were Egtved virus (VHSV) and Rhabdovirus anguilla (EVX). Strips: 1, EVX with gold; 2, VHSV with serum from non-immunized mouse; $3, \mathrm{VHSV}$ and 4 , EVX both with serum from mice immunized with VHSV; 5 , VHSV and 6, EVX both with G-specific MAb G-gol type (IP1D11); 7, VHSV and 8, EVX both with G-specific MAb G-ret type (IP1H3); 9 , VHSV and 10, EVX both with N-specific MAb (IP5B11); 11, VHSV and 12, EVX both with $\mathrm{M}_{1}$-specific MAb (IP1C6); 13 , VHSV and 14, EVX both with $\mathrm{M}_{2}$-specific MAb (IP1C3); 15 , VHSV with gold. Mouse sera were diluted 1000 times in PBST-BSA. HSNs were diluted to about $30 \mathrm{ng}$ mouse $\mathrm{Ig} \mathrm{ml} \mathrm{ml}^{-1}$. Strips were incubated $2 \mathrm{~h}$ at room temperature with the primary antibody. Other parameters as described in the text

and most monospecifically reacting HSNs were cloned. After cloning monospecifically reacting HSNs were analysed in IFAT. Five different staining patterns of virus-infected cells were observed, correlating with the different protein specificities seen by immunoblotting. Cell clones representing each of the 5 patterns were selected for further propagation.

\section{Immunoblotting}

Immunoblotting results with the 5 finally selected cell lines are shown in Fig. 1. None of the HSNs from these cells reacted with a cellular control antigen (not illustrated) or with EVX virus proteins. It appeared that anti-M $\mathrm{M}_{2} \mathrm{MAb}$ cross-reacted slightly with the $\mathrm{N}$ protein and anti-N MAb possibly slightly with the $\mathrm{M}_{2}$-protein.
However, monospecificity in immunoblotting turned out to be a matter of dilution factors since all the antibodies showed some faint shadow-like staining of protein bands other than the intensively stained main band, if a high concentration of MAb was used.

\section{ELISA}

As shown in Fig. 2 the 5 selected MAbs of different specificity reacted with different intensities in ELISA. The intensity of the reactions decreased in the following order: anti- $\mathrm{M}_{2}$, anti-N, anti-M $\mathrm{M}_{1}$ and anti-G.

None of the HSNs reacted with EVX virus in ELISA (not shown).

\section{IFAT}

The IFAT reaction of HSNs, previously characterized by immunoblotting, with Egtved virus-infected cell cultures, fixed 24 h p. i., are shown in Fig. 3. Antibody against the N-protein (Fig. 3d) gave a strong, coarsely granular staining primarily of the peripheral part of the cytoplasma in the majority of the infected cells. Antibody against $M_{1}$ induced a staining which resembled that of anti- $\mathrm{N}$ but less intensive. Anti- $\mathrm{M}_{1}$ additionally stained membranes or membrane-associated material (Fig. 3e).

Antibody reacting with $M_{2}$ caused a fine granular staining throughout the cytoplasm. Furthermore, the cell membranes including membrane protusions were stained (Fig. 3f).

The reaction of antibodies specific for the G-protein showed 2 different patterns varying from one HSN to another. One of the patterns involved staining of reticular structures, in some cells more evidently than in others, evenly distributed throughout the cytoplasm. In most of the infected cells cisternae-like structures in a juxtanuclear position were stained as well. The specificity of the antibody in question is referred to as anti-G-reticular (anti-G-ret) (Fig. 3a, b).

The other pattern involved staining of the cisternaelike structures close to the nucleus (probably some Golgiassociated structures) mentioned above and in addition a faint staining of cell membranes. The specificity of this antibody is referred to as anti-G-gol (Fig. 3c).

None of the HSNs examined reacted with EVX or SVC (not shown).

In order to obtain information about the earliest possible detection of the respective proteins in the infected cells, the 5 HSNs were applied on Egtved virusinfected EPC-cell cultures fixed at $1 \mathrm{~h}$ intervals $\mathrm{p}$. $\mathrm{i}$. The results appear in Table 1 . The proteins became detectable in the following order: $N$ (1 to $2 \mathrm{~h} \mathrm{p}$. i.), $\mathrm{M}_{1}(6 \mathrm{~h}$ p. i.), G-gol and G-ret ( 7 to 8 h p. i.) and $M_{2}$ ( 8 h p. i.). 


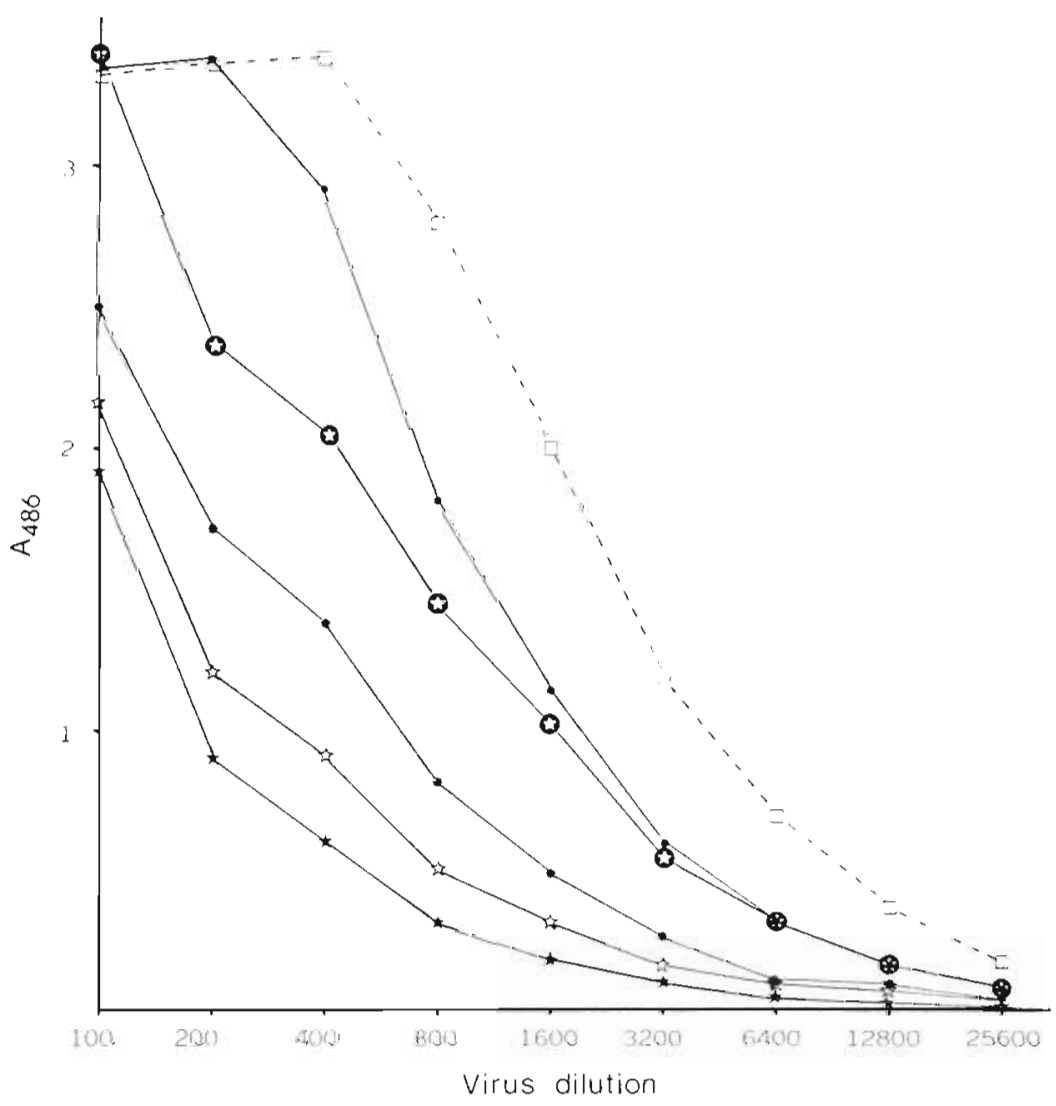

Fig. 2. Relation between $A_{486}$ and dilution of gradient-purified Egtved virus in ELISA with the 5 finally selected MAbs and mouse serum as primary antibodies. HSNs were diluted to about $1 \mu \mathrm{g}$ mouse Ig $\mathrm{ml}^{-1}$; sera from VHSV-immunized mice were diluted 10000 times. Other parameters as in Materials and Methods'. The reaction was stopped after 15 min. (*) G-specific MAb (G-gol) IP1D11; $\Leftrightarrow$ G-specific MAb (G-ret) IP1H3; (0) N-specific MAb IP5B11; (*) $\mathrm{M}_{1}$-specific MAb IP1C6; (•) $\mathrm{M}_{2}$-specific MAb IPiC3; ( $\square$ ) mouse serum $\left(10000^{-1}\right)$

\section{DISCUSSION}

An important prerequisite for the success of the present work was the initial development of the ELISA technique as a simple specific way of detecting Egtved virus-specific antibodies in HSNs. So far other workers have had little success in applying ELISA techniques in the study of Egtved virus (Dixon \& Hill 1984). The use of gradient-purified virus in the coating layer is probably an important step.

It would have been possible to use IFAT instead of ELISA during the initial screening but this would have been very time-consuming.

Immunoblotting results (Fig. 1) revealed that the initial ELISA screening was sensitive enough to detect antibodies reacting with 4 of the 5 known polypeptides in the virion. However, antibodies specific for the Gprotein in general gave ELISA reactions near the detection limit (Fig. 2). This means that some G-reactive MAbs of moderate or low affinity, or perhaps directed against less exposed determinants, might remain undetected. Bernard et al. (1985) have estimated that the G-protein makes up only about $7 \%$ of total virion protein mass. The percentage of $\mathrm{L}$-protein is even smaller and furthermore the L-protein is a highmolecular-weight structure (about $190 \mathrm{kd}$ ). It thus appears that a MAb directed against an unrepeated determinant on $\mathrm{L}$ might very easily remain undetected.

Detection of L-specific MAbs in HSNs would probably require use of immunoblotting in the screening step. Even then difficulties might be encountered due to incomplete transfer of the L-band to the nitrocellulose membrane. Alternatively an ELISA with a heavy protein load in the coating step might prove usable, the main problem being an often high background level in the initial screening. Concerning the $G_{-}, N_{-}, M_{1}-$ and $\mathrm{M}_{2}$-proteins, immunoblotting seems to be quite a sensitive procedure in detecting low concentrations of specific MAbs. In fact HSNs from well-established cell lines could often be diluted about 8000 times and still give strong staining reactions. The observed crossreaction of $\mathrm{M}_{2}$-specific MAbs with the $\mathrm{N}$-band was not seen in high dilutions of HSN. However, the crossreaction pattern appeared with all of $4 \mathrm{M}_{2}$-reactive HSNs after cloning and therefore occurrence of some partially identical epitopes in the 2 protein bands cannot be excluded.

Several authors, however, have lately demonstrated the occurrence of different kinds of cross-reacting MAbs, which consequently may be more common than previously expected (Fox \& Siraganian 1986, Ghosh \& Cambell 1986). 

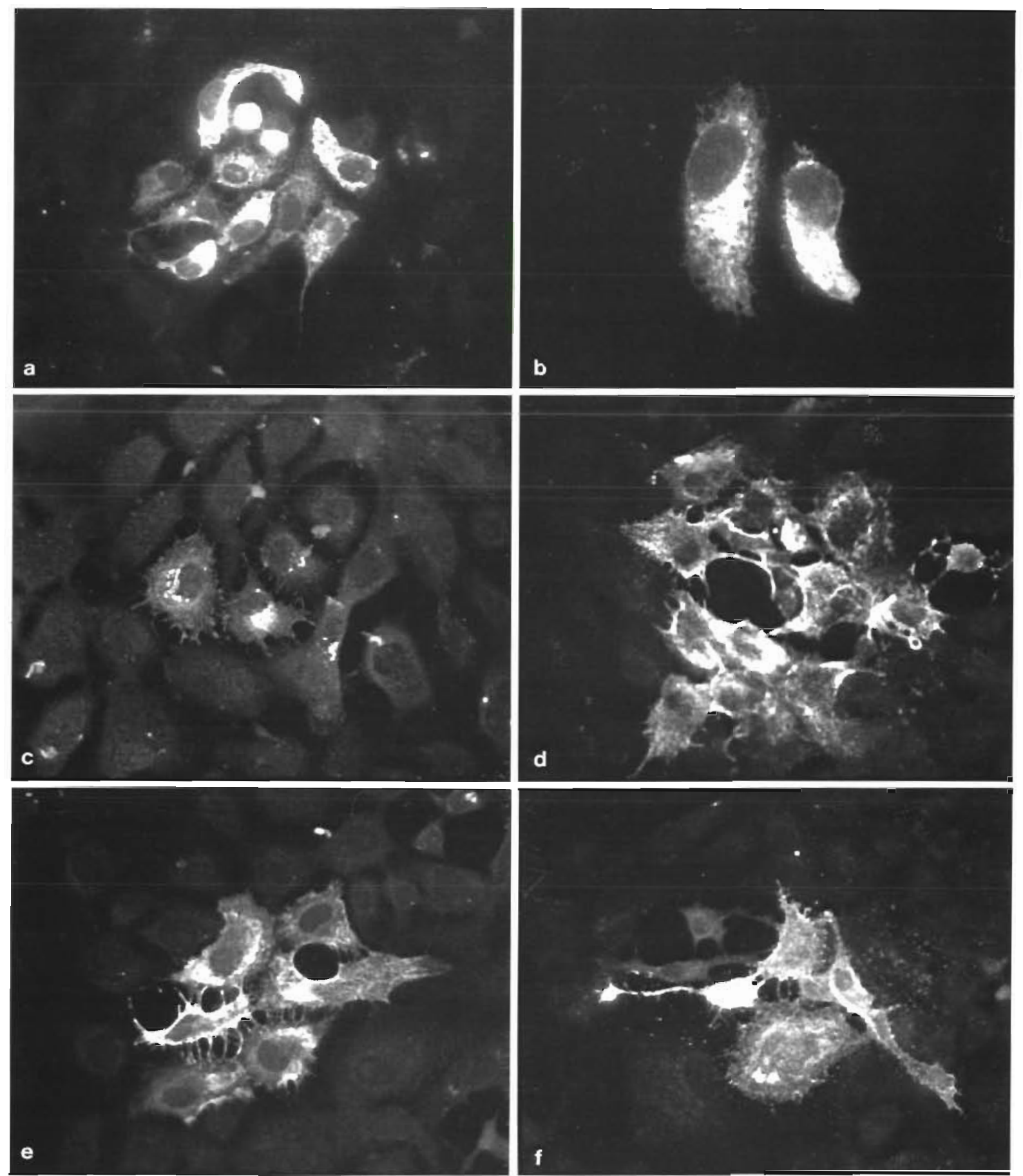

Fig. 3. Immunofluorescence micrographs illustrating the celiular staining patterns seen in Egtved virus-infected EPC cells fixed 24 h p.i. and examined with protein-specific MAbs as primary antibodies. (a) G-specific MAb, reticular type, $\times 370$. (b) Same, $\times 880$ (c) G-specific MAb, Golgi type, $\times 370$. (d) N-specific MAb, $\times 370$. (e) $\mathrm{M}_{1}$-specific MAb, $\times 370$. (f) $\mathrm{M}_{2}$-specific MAb, $\times 370$

In IFAT each antibody gave a characteristic staining pattern depending on the specificity Similar results have been reported for vesicular stomatitis virus (VSV) which belongs to the vesiculo group in the rhabdovirus family (for review see Dubois-Dalcq et al. 1984). The findings in this study concerning Egtved virus protein $N$ and $M_{1}$ correspond well to the intracellular distribution of the VSV proteins N and NS respectively The staining of peripheral cytoplasmic material probably concerns nucleocapsids immediately before the bud- 
ding process. The staining of Golgi-like structures as well as membrane components by G-specific antibodies is a common phenomenon (Wehland et al. 1981, Bergmann et al. 1982). Conversely, the characteristic reticular pattern seen with the G-ret-specific antibodies does not seem to be a common observation in IFAT studies. Electron microscopical analysis, however, has proved the presence of viral glycoprotein in the endoplasmatic reticulum of VSV-infected cells (Wehland et al. 1981, Bergmann et al. 1982). Presumably the reticular pattern in IFAT is due to selection of a MAb directed against a glycoprotein determinant which is well exposed in the endoplasmatic reticulum.

The G-gol-specific antibodies probably react only with determinants added to (or demasked on) the Gmolecule during its passage through the Golgi apparatus of the host cell.

In the study of the time of intracellular appearance for the different virion proteins, $N$ was first to be detected followed by $M_{1}, G$ and $M_{2}$ (Table 1 ). A nearly similar order of detection by means of radiochemical methods has been reported for IHNV, another fish rhabdovirus (Hsu et al. 1985).

Varying degrees of background staining with the different MAbs in IFAT made early detection of some proteins easier than others. The very early appearance (1 to $2 \mathrm{~h}$ ) of $\mathrm{N}$, however, is very significant and may reflect the function of the $\mathrm{N}$-protein in genome folding and protection (Dubois-Dalcq et al. 1984).

With regard to rapid detection of Egtved virus by means of IFAT, our results have pointed out anti-N MAbs as potentially valuable specific reagents.

In ELISA $\mathrm{M}_{2}$-specific MAb gave a very strong reaction with the F1 antigen and a reaction with the control antigens near background level, indicating easy and specific detection of the $\mathrm{M}_{2}$ protein in this kind of assay. In concordance with this, Bernard et al. (1985) have found $\mathrm{M}_{2}$ to be the dominating protein in the virion.

Table 1. Characteristics of 5 selected MAbs

\begin{tabular}{|c|c|c|c|}
\hline $\begin{array}{l}\text { Hybridoma } \\
\text { cell line }\end{array}$ & $\begin{array}{c}\text { Protein } \\
\text { specificity }\end{array}$ & $\begin{array}{l}\text { Immuno- } \\
\text { globulin } \\
\text { class' } \\
\text { subclass }\end{array}$ & $\begin{array}{l}\text { Time lapse } \\
\text { p.i. until } \\
\text { positive IFAT } \\
\text { reaction }{ }^{a} \\
\text { (h) }\end{array}$ \\
\hline IP1D11 & $G(G-g d)$ & $\operatorname{Ig}_{1}$ & $7-8$ \\
\hline IP1H3 & $G(G$-ret) & $\operatorname{IgG}_{1}$ & $7-8$ \\
\hline IP5B11 & $N$ & $\operatorname{IgG}_{1}$ & $1-2$ \\
\hline IP1C6 & $M_{1}$ & $\mathrm{IgG}_{2 b}$ & 6 \\
\hline IP1C3 & $M_{2}$ & $\operatorname{IgG}_{1}$ & 8 \\
\hline
\end{tabular}

None of the 92 HSNs tested in $50 \%$ PNT contained detectable amounts of neutralizing antibody. Neither could neutralizing antibodies be detected in serum samples from the immunized mice at the time when the spleens were removed for fusion. After 6 mo of continued immunization of other mice low titres of neutralizing antibodies were synthesized. It remains to be seen whether the use of spleen cells from such a mouse for fusion might lead to hybridomas producing Egtved virus neutralizing antibodies.

The present MAbs appear to represent potentially valuable tools for future VHS studies. We intend to use them in immunosorbent work for preparation of pure Egtved virus polypeptides which will be essential in connection with immunization- and pathogenesis studies. In addition to being useful in basic VHS studies the MAbs seem to be potentially powerful diagnostic tools.

Acknowledgements. Niels Foged and Per Qvist at the Hybridoma Laboratory of the National Veterinary Laboratory, Copenhagen, are thanked for indispensable technical advice as well as helpful discussions in connection with the hybridoma work. We also gratefully acknowledge the instructions and the standard reagent supplied by Dr Claus Koch, the State Serum Institute, Copenhagen, for use in the quantitative ELISA.

\section{LITERATURE CITED}

Astaldi, G. C. B., Janssen, M. C., Lansdorp, P., Willems, C. Zeilemarker, W. P., Oosterhof, F. (1980). Human endothellial culture supernatant (HECS): a growth factor for hybridomas. J. immunol. 125 (4) : 1411-1414

Bergmann, J. E., Tokoyasu, K. T., Singer, S. J. (1982). Passage of an integral membrane protein, the vesicular stomatitis virus glycoprotein, through the Golgi apparatus en route to the plasma membrane. Proc. natl Acad. Sci. U.S.A. 78 (3): 1746-1750

Bernard, J., Bearzotti-LeBerre, M., de Kinkelin, P. (1985). Viral Haemorrhagic Septicaemia in rainbow trout: attempt to relate interferon production, antibody synthesis and structure of the virus with the mechanism of virulence. Annls Inst. Pasteur/Virol. 136 E: 13-26

Dixon, P. F., Hill, B. J. (1984). Rapid detection of fish rhabdoviruses by the enzyme-linked immunosorbent assay (ELISA). Aquaculture 42: 1-12

Dubois-Dalcq, M., Holmes, K. V., Rentier, B. (1984). Assembly of enveloped RNA viruses. Springer Verlag Wien, New York

Fijan, N., Petrinec, Z., Sulimanovic, D., Zwillenberg, L. O. (1971). Isolation of the viral causative agent from the acute form of infectious dropsy of carp. Veterinarski Archiv 41: $125-138$

Fijan, N., Sulimanovic, D., Bearzotti, M., Muzinic, D., Zwillenberg, L. O., Chilmonczyk, S., Vauthorst, J. F., de Kinkelin, P. (1983). Some properties of the Epithelioma Papulosum Cyprini (EPC) cell line from carp (Cyprinus carpio). Annls Inst. Pasteur/Virol. 134 E: 207-220

Fox, P. C., Siraganian, R. P. (1986). Multiple reactivity of monoclonal antibodies. Hybridoma 5 (3): 223-229 
Ghosh, S., Cambell, A. M. (1986). Multispecific monoclonal antibodies. Immunology Today $7(7-8): 217-221$

Hill, B. J., Williams, R. F., Smale, C. J., Underwood, B. O., Brown, F. (11980). Physiochemical and serological characterization of two rhabdoviruses isolated from eels. Intervirology 14: 208-212.

Hsu, Y., Engelking, H. M., Leong. J. C. (1985). Analysis of the quantity and synthesis of the virion proteins of Infectious Hematopoetic Necrosis Virus. Fish Path. 20 2/3: 331-338

Jensen, M. H. (1965). Research on the virus of Egtved disease. Ann. N. Y. Acad. Sci. 126: 422-426

Jørgensen, P. E. V (1974). Indirect fluorescent antibody techniques for demonstration of trout viruses and corresponding antibody. Acta. Vet. Scand. 15: 198-205

Kearney, J. F., Radbruch, A., Liesegang, B., Rajewsky, K. (1979). A new mouse myeloma cell line that has lost the immunoglobulin expression but permits the construction of antibody secreting hybrid cell lines. J. Immunol. 123 (4): $1548-1550$

Kinkelin, P. de (1972). Le virus d'Egtved. II. Purification. Ann. Rech. vétér. 1972: 199-208

Kinkelin, P, de, Bernard, J., Hattenberger-Baudouy, A.-M. (1984). Immunization against viral diseases occurring in cold water. In: Kinkelin, P. de (ed.) Symposium on fish vaccination. Office International des Epizooties, Paris, p. $167-197$

Kyhse-Andersen, J. (1984). A simple horizontal apparatus without buffer tank for electrophoretic transfer of proteins from polyacrylamide to nitrocellulose. J. Biochem biophys. Methods 72: 471

Laemmli, U. K. (1970). Clevage of structural proteins during assembly of the head of bacteriophage T4. Nature, Lond. 227: $680-685$

Lenoir, G., de Kinkelin, P. (1975). Fish rhabdoviruses: comparative study of protein structure. J. Virol. 16 (2): 259-262
Macart, M., Gerbaut, L. (1982). An improvement of the coomassie blue dye binding method allowing an equal sensitivity to various proteins: application to cerebrospinal fluid. Clinica Chemica Acta 122: 93-101

McAllister, P. E., Wagner, R. R. (1975). Structural proteins of two salmonid rhabdoviruses. J. Virol. 15 (4): 733-738

Moremans, M., Daniels, G., De May, J. (1985). Sensitive colloidal metal (gold or silver) staining of protein blots on nitrocellulose membranes. Analyt. biochem. 145: 315-321

Morrissey, J. H. (1981). Silver stain for proteins in Polyacrylamide gels: a modified procedure with enhanced uniform sensitivity. Analyt. biochem. 117: 307-310

Olesen, N. J., Jorgensen, P. E. V. (1986). Detection of neutralizing antibodies to Egtved virus in rainbow trout (Salmo gairdneri) by plaque neutralization test with complement addition. J. appl. Ichthyol. 2 (1): 33-41

Rygaard, J., Olsen, V (1969). Interference filters for improved immunofluorescence microscopy. Acta Path. Microbiol Scand. 76: 146-148

Rylatt, d. B., Parish, C. R. (1982). Protein determination on an automatic spectrophotometer. Analyt. Biochem. 121: $213-214$

Voller, A., Bidwell, D. E., Bartlett, A. (1979). The enzymelinked immunosorbent assay (ELISA). A guide with abstracts of microplate applications. Dynatech Europe, Borough House, Guernsey

Wehland, J., Willingham, M. C., Gallo, M. G., Pastan, I. (1981). The morphologic pathway of exocytosis of the vesicular stomatitis virus $G$ protein in cultured fibroblasts. Cell 28: 831-841

Wagner, R. R., Prevec, L., Summers, D. F., Sokol, F., McLeod, R. (1972). Classification of rhabdovirus proteins: a proposal. J. Virol. 10: 1228-1230

Wolf, K., Quimby, M. C. (1962). Established erythermic line of fish cells in vitro. Science 135: 1065-1066 